\title{
Allgemeine Strafrechtslehre
}

Eine lehrbuchmäßige Darstellung

\author{
Yon \\ Wilhelm Sauer \\ Professor an der Universität Münster
}

3., völlig neue Auflage der

"Grundlagen des Strafrechts"

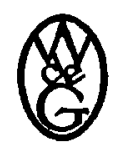

Berlin 1955

Walterde Gruyter\& Co.

vornals G. J. Göschen'sche Verlagshandlung - J. Guttentag, Verlagsbuchhandlung Georg Reimer - Karl J. Trübner - Veit \& Comp. 
Archiv Nr. 232755

Satz: Walter de Gruyter \& Co.

Druck: Berliner Bucharuckerei Union GmbH., Berlin SW 29 Alle Rechte, einschließlich des Rechtes der Herstellung von Photokopien und Mikrofilmen, vorbehalten 